\title{
A Desirability Function for Evaluation of Corrosion Behavior for Nanocoated- Steel Using Electroless Technique
}

\author{
Muroog M. Shinyar ${ }^{\text {a*, }}$, Abbas Kh. Hussein ${ }^{\text {b }}$, Laith K. Abbas \\ ${ }^{a}$ Materials Engineering Department, University of Technology - Baghdad - Iraq, \\ mae.19.18@grad.uotechnology.edu.iq

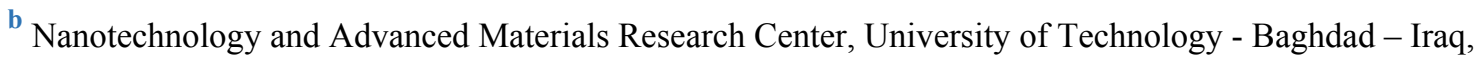 \\ 130032@uotechnology.edu.iq \\ c Materials Engineering Department, University of Technology - Baghdad - Iraq, \\ 130039@uotechnology.edu.iq
}

*Corresponding author.

Submitted: $16 / 02 / 2021$

Accepted: 08/04/2021

Published: 25/06/2021

\section{K E Y W O R D S}

Electroless deposition, corrosion resistance, nanocomposite, coating \& Taguchi Method.

\section{A B S T R A C T}

The current work is conducting an experimental investigation into the effect of those technical parameters, called nanomaterial, bath temperature and plating time on the micro-hardness and corrosion rate of electroless plated low carbon steel undergoing electroless deposition operation. It was used to prepare ( $\mathrm{Ni}-\mathrm{P} / \mathrm{Nano} \mathrm{TiO} \mathrm{O}_{2}$ ), ( $\mathrm{Ni}-\mathrm{P} / \mathrm{Nano} \mathrm{Al}_{2} \mathrm{O}_{3}$ ) and $\left(\mathrm{Ni}-\mathrm{P} / \mathrm{Nano} \mathrm{SiO}_{2}\right.$ ) alloys in this research. The Taguchi design is used to describe the variations located within the corrosion and mechanical properties. To achieve a comprehensive study, a Taguchi-based design was used to account for all applicable combinations of factors. Experimental models had been advanced that linking the response and method parameters to the results of those experiments. Validation of these models is done using analysis of variance (ANOVA). The desirability function is used to simultaneously optimize all the response. Finally, the optimum combination of method parameters resulting (bath temperature $=90^{\circ} \mathrm{C}$, plating time $=120 \mathrm{~min}$. and Nanomaterial $=($ Al2O3 $\left.)\right)$, nanomaterial was observed to be the major process parameter on the responses of the electroless-plated low carbon steel with an impact ratio of (47\%) based on the (ANOVA) results.

How to cite this article: M. M. Shinyar, A. Kh. Hussein, and L. K. Abbas, "A Desirability Function for Evaluation of Corrosion Behavior for Nanocoated- Steel Using Electroless Technique,” Engineering and Technology Journal, Vol. 39, No. 06, pp. 946-955, 2021. DOI: https://doi.org/10.30684/etj.v39i6.2009

This is an open access article under the CC BY 4.0 license http://creativecommons.org/licenses/by/4.0

\section{INTRODUCTION}

Corrosion is the damage to metals because of their interaction with a corrosive agent in their environment, like chlorine, fluorine, carbon dioxide, oxygen, etc. Corrosion may be avoided through surface modifications; this is obtained through utilizing physical barriers which includes films and 
coatings to decrease cracks. Because of the broad range of current and potential coating materials and coating techniques for many conditions and applications, coating is the most utilized technique for preventing, reducing, or regulating corrosion [1]. Coating is a method of finishing the surface of an object, normally as the substrate. Coatings are applied to enhance substrate surface properties, like mechanical properties, adhesion, wettability, corrosion resistance, wear resistance [2]. Recently, nanomaterials were added as an effective method to decrease corrosion. Nanomaterials are materials from at least one of their morphological features which includes grain size, particle size, structure size, etc. The nanoscale (less than $100 \mathrm{~nm}$ ). Nanomaterials have advanced thermal, mechanical, physical, chemical, magnetic, electrical, and optical properties, they can be zero dimensional (nanoparticles), one dimensional (nanotubes, nanowires, and nanorods), or two dimensional (nanoplatelet, nanosheets, and nanofilms. This is because of their small sizes, which allows for larger volume fractions on the surfaces and because of higher interaction areas [1]. Nanomaterials are promising in reducing the corrosion rate of the metal substrates through surface modification with coating. Nickel (EN) coatings were commonly used in the aerospace, mechanical, and chemical industries. [3]. It has many advantages because of its low device cost, easy in operation, and the formation capacity of very thin and uniform coating on each conductive and non-conductive surface [4]. In an electroless plating reaction, nickel ions are catalytically decreased to active substrates without utilized electrical energy, as a result, the electrons required for reduction reaction are supplied through cochemical reducing agent [3]. Nickel-phosphorous (Ni-P) plating is the product of one of the major cochemical reducing agents, phosphorous, and the alloy has excellent mechanical, electrical, magnetic, and anticorrosive properties. One of the most important factors in electroless technique is the content and characteristics of the bath solutions. The influence of those conditions on numerous substrates that have a high major effect at the deposition rate, structure of chemical composition and coating film quality were extensively studied in the past [5-6]. It has also been utilized as an additive in electroless (Ni-P) plating, due to recent advances in nanoparticle technology and their fields of application [7]. Solid particles including alumina, titanium oxide, silicon carbide, and silicon nitride are added to an electroless coating solution to create a composite coating [8]. As compared to plane (Ni-P) electroless coatings, these coatings have the best physio-mechanical properties. One of the prime properties which has proved to be of significance in successful applications is hardness [9]. The microhardness of the surface has an extensive effect on mechanical properties including fatigue behavior, resistance to corrosion and creep life. As a result, development in the modeling of surface microhardness and optimization of control parameters is required to achieve the desired degree of surface microhardness. It is therefore necessary to maximize the mean microhardness of the products [10-11]. The aim of this research is to improve the corrosion and mechanical properties of the low carbon steel substrate by electroless coating with $\left(\mathrm{Ni}-\mathrm{P}-\mathrm{TiO}_{2}\right),(\mathrm{Ni}-$ $\left.\mathrm{P}-\mathrm{Al}_{2} \mathrm{O}_{3}\right)$ and (Ni-P- $\mathrm{SiO}_{2}$ ) Nano coating and find the optimal coating conditions for the proper hardness and corrosion by Taguchi method.

\section{EXPERIMENTAL}

\section{Substrate deposition and preparation}

Low carbon steel samples with the dimensions $(1.5 \mathrm{~cm} \times 1.5 \mathrm{~cm} \times 0.5 \mathrm{~cm})$ were used as substrates. The chemical structure of the low carbon steel shows in the Table I by using Spectra Max at (The General Company for Engineering Inspection and Rehabilitation):

TABLE I: Chemical composition of low carbon steel

\begin{tabular}{cccccccccccc}
\hline \hline Element & $\mathbf{C}$ & $\mathbf{S i}$ & $\mathbf{M o}$ & $\mathbf{S}$ & $\mathbf{P}$ & $\mathbf{N i}$ & $\mathbf{M n}$ & $\mathbf{A l}$ & $\mathbf{C r}$ & $\mathbf{P b}$ & $\mathbf{F e}$ \\
\hline $\mathrm{Wt} \%$ & 0.13 & 0.007 & 0.00 & 0.005 & 0.008 & 0.032 & 0.52 & 0.052 & 0.004 & 0.003 & $\mathrm{Ba}$ \\
& 9 & 2 & 2 & 3 & 8 & 4 & 6 & 2 & 4 & 0 & 1 \\
\hline
\end{tabular}

Then specimens washed at room temperature in an alkaline solution $(1 \mathrm{M} \mathrm{KOH})$ after which successively rinsed with suitable deionized waters for 15 minutes. Before the deposition, the steel sample cleaning is accomplished as follows; the samples had been mechanically polished to (2000) grade with emery papers, and carefully processed at a $(50 \%)$ dilute $(\mathrm{HCl})$ solution. Specimens had been washed with water, dried manually through a piece of cotton after which washed through methanol. Samples after washing with methanol had been rinsed and dried in an oven. The samples 
then had been immersed in the (Ni-P) deposition bath instantly and then added the nanoparticles to the solution. Samples are removed from solution and clean in distilled water. Table II shows the tank composition for the (Ni-P) Nano $\left(\mathrm{TiO}_{2}\right)$ electroless deposition. The tank is run at $\left(80{ }^{\circ} \mathrm{C}\right.$ to $\left.100{ }^{\circ} \mathrm{C}\right)$ with a $(\mathrm{pH}=5)$ solution for (40 minutes to 120 minutes) of plating time.

TABLE II: Tank composition for (Ni-P) Nano $\left(\mathrm{TiO}_{2}\right)$ deposition

\begin{tabular}{cc}
\hline \hline Substance & Concentration (g/L) \\
\hline $\mathrm{NiSO}_{4} \cdot 6 \mathrm{H}_{2} \mathrm{O}$ & 30 \\
\hline $\mathrm{NaH}_{2} \mathrm{PO}_{2}$ & 25 \\
\hline $\mathrm{Na}_{3} \mathrm{C}_{6} \mathrm{H}_{5} \mathrm{O}_{7} \cdot \mathrm{H}_{2} \mathrm{O}$ & 20 \\
\hline $\mathrm{Thiourea}$ & 0.002 \\
\hline Nano $\mathrm{TiO}_{2}$ & 3
\end{tabular}

Table III shows the bath of composition for (Ni-P) Nano $\left(\mathrm{Al}_{2} \mathrm{O}_{3}\right)$ electroless deposition. The bath was worked at $\left(80^{\circ} \mathrm{C}\right.$ to $\left.100^{\circ} \mathrm{C}\right)$ with a $(\mathrm{pH}=5)$ solution for $(40$ minutes to 120 minutes) of plating time.

TABLE III: Tank composition for (Ni-P) $\mathrm{Nano}\left(\mathrm{Al}_{2} \mathrm{O}_{3}\right)$ deposition

\begin{tabular}{cc}
\hline \hline Substance & Concentration (g/L) \\
\hline $\mathrm{NiSO}_{4} \cdot 6 \mathrm{H}_{2} \mathrm{O}$ & 30 \\
\hline $\mathrm{NaH}_{2} \mathrm{PO}_{2}$ & 25 \\
\hline $\mathrm{Na}_{3} \mathrm{C}_{6} \mathrm{H}_{5} \mathrm{O}_{7} \cdot \mathrm{H}_{2} \mathrm{O}$ & 20 \\
\hline $\mathrm{Thiourea}$ & 0.002 \\
\hline Nano $\mathrm{AL}_{2} \mathrm{O}_{3}$ & 3 \\
\hline
\end{tabular}

Table IV shows the bath of composition for (Ni-P) Nano $\left(\mathrm{SiO}_{2}\right)$ electroless deposition. The bath was worked at $\left(80^{\circ} \mathrm{C}\right.$ to $\left.100{ }^{\circ} \mathrm{C}\right)$ with a $(\mathrm{pH}=5)$ solution for $(40$ minutes to 120 minutes $)$ of plating time in each experiment, $(200 \mathrm{~mL})$ of fresh bath solution was selected.

TABLE IV: Tank composition for (Ni-P) $\operatorname{Nano}\left(\mathrm{SiO}_{2}\right)$ deposition

\begin{tabular}{cc}
\hline \hline Substance & Concentration (g/L) \\
\hline $\mathrm{NiSO}_{4} \cdot 6 \mathrm{H}_{2} \mathrm{O}$ & 30 \\
\hline $\mathrm{NaH}_{2} \mathrm{PO}_{2}$ & 25 \\
\hline $\mathrm{Na}_{3} \mathrm{C}_{6} \mathrm{H}_{5} \mathrm{O}_{7} \cdot \mathrm{H}_{2} \mathrm{O}$ & 20 \\
\hline Thiourea & 0.002 \\
\hline Nano $\mathrm{SiO}_{2}$ & 3 \\
\hline
\end{tabular}

\section{Microhardness measurements}

Microhardness of electroless (Ni-P) Nano $\left(\mathrm{TiO}_{2}\right)$, (Ni-P) Nano $\left(\mathrm{Al}_{2} \mathrm{O}_{3}\right)$ and (Ni-P) Nano $\left(\mathrm{SiO}_{2}\right)$ coatings, were determined. To cause the indentations in all deposits, a constant load of (100) $\mathrm{g}$ was applied, and the hardness values were averaged out of three such determination. The test was done in (Department of Materials Engineering - University of Technology - Baghdad - Iraq), as shown in Figure 1:

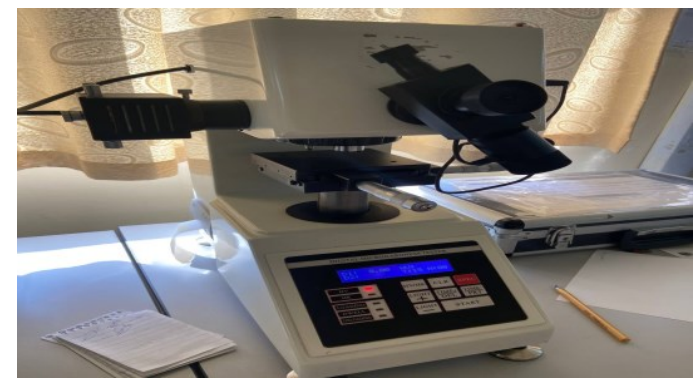

Figure 1: Microhardness test device. 


\section{Taguchi method}

The Taguchi approach is an effective tool for designing high quality systems that depends on orthogonal array experiments which offer much-lower contrast for experiments with an optimum setting of method manage parameters. In addition, this technique has been widely applied in engineering analysis to improve performance characteristics through design parameter settings. Its several advantages such as:(1) Designs Orthogonal arrays (OA) to reduce test operations and balance the parameters of process. (2) Uses the signal-to-noise $(\mathrm{S} / \mathrm{N})$ ratio to analyze experiment data, and to infer more information. (3) Evaluations the contributions of individual parameters [12]. The Taguchi approach relies on orthogonal arrays and analysis of variance (ANOVA) to limit the number of experiments and to effectively enhance product quality [13]. The Taguchi principle include two important factors: (the control factor) and (the noise factor) which are usually used to study the effect of responses. The input factors are used to select the appropriate conditions for process, while the noise parameters denote, all parameters that cause negative effects [14].

It has been found that the properties of electroless coating are influenced by many factors consisting of bath temperature, plating time, coating composition using nanomaterial, stabilizer concentration, $\mathrm{pH}$ of the solution, substrate, bath load, etc. The experimental design is very complicated, and the analysis is even more difficult. A review of the modern literatures discovered that the three factors are: bath temperature (A), plating time (B) and coating composition using nanomaterials $(\mathrm{C})$ are the usually preferred factors that are utilized through the researchers to govern the properties of electroless nickel deposits. The response mechanism begins with the bath temperature and then controls the process of ionization and charge transfer to determine the rate of reaction. The studied design parameters and their levels are shown in Table V. The use of three levels allows for the investigation of any non-linear effects.

TABLE V: Design parameters and their levels

\begin{tabular}{lccccc}
\hline \hline \multirow{2}{*}{ Design Factors } & Unit & \multicolumn{3}{c}{ Levels } \\
\cline { 3 - 5 } & & $\boldsymbol{1}$ & $\mathbf{2}$ & $\mathbf{3}$ \\
\hline Bath temperature A & & & 80 & 90 & 100 \\
\hline Plating time & $\mathrm{B}$ & $\mathrm{C}$ & 40 & 80 & 120 \\
\hline Nano-material & $\mathrm{C}$ & - & $\mathrm{TiO}_{2}$ & $\mathrm{Al}_{2} \mathrm{O}_{3}$ & $\mathrm{SiO}_{2}$ \\
\hline
\end{tabular}

The number of degrees of freedom for a given parameter in the context of (DOE) is one less than the number of levels linked with the parameter of the principal factors is currently linked to three levels, each of which (DOE) of the factors is two. It is important to note that the number of training procedures in the (OA). Twenty- seven experimental trials are required to be suitably chosen for the current state. The task Orthogonal Array (OA) must be greater than the total (DOE) required for analyzing the effects. As a result, (L27) and (OA) of the factors to the array's columns are done using the Triangular Table for (3-level) arrays (OA). Table VI shows the $\left(\mathrm{L}_{27} \mathrm{OA}\right)$ as well as the column assignments. The levels of the key parameter columns (A, B, and C) in the array are represented by the values in each cell (1,2 and 3).

TABLE VI: $\left(L_{27}\right)$ orthogonal array with main parameters

\begin{tabular}{ccccc}
\hline \hline $\begin{array}{l}\text { Exp. } \\
\text { No. }\end{array}$ & Nano material & Bath Temperature $\left({ }^{\mathbf{0}} \mathbf{C}\right)$ & Plating Time (min.) & Speed of stirring \\
\hline 1 & $\mathrm{TiO}_{2}$ & 80 & 40 & 500 \\
\hline 2 & $\mathrm{TiO}_{2}$ & 80 & 80 & 500 \\
\hline 3 & $\mathrm{TiO}_{2}$ & 80 & 120 & 500 \\
\hline 4 & $\mathrm{TiO}_{2}$ & 90 & 40 & 500 \\
\hline 5 & $\mathrm{TiO}_{2}$ & 90 & 80 & 500 \\
\hline
\end{tabular}




\begin{tabular}{ccccc}
\hline 6 & $\mathrm{TiO}_{2}$ & 90 & 120 & 500 \\
\hline 7 & $\mathrm{TiO}_{2}$ & 100 & 40 & 500 \\
\hline 8 & $\mathrm{TiO}_{2}$ & 100 & 80 & 500 \\
\hline 9 & $\mathrm{TiO}_{2}$ & 100 & 120 & 500 \\
\hline 10 & $\mathrm{Al}_{2} \mathrm{O}_{3}$ & 80 & 40 & 500 \\
\hline 11 & $\mathrm{Al}_{2} \mathrm{O}_{3}$ & 80 & 80 & 500 \\
\hline 12 & $\mathrm{Al}_{2} \mathrm{O}_{3}$ & 120 & 500 \\
\hline 13 & $\mathrm{Al}_{2} \mathrm{O}_{3}$ & 40 & 40 & 500 \\
\hline 14 & $\mathrm{Al}_{2} \mathrm{O}_{3}$ & 90 & 80 & 500 \\
\hline 15 & $\mathrm{Al}_{2} \mathrm{O}_{3}$ & 90 & 120 & 500 \\
\hline 16 & $\mathrm{Al}_{2} \mathrm{O}_{3}$ & 40 & 500 \\
\hline 17 & $\mathrm{Al}_{2} \mathrm{O}_{3}$ & 100 & 80 & 500 \\
\hline 18 & $\mathrm{Al}_{2} \mathrm{O}_{3}$ & 100 & 120 & 500 \\
\hline 19 & $\mathrm{SiO}_{2}$ & 100 & 40 & 500 \\
\hline 20 & $\mathrm{SiO}_{2}$ & 80 & 80 & 500 \\
\hline 21 & $\mathrm{SiO}_{2}$ & 80 & 120 & 500 \\
\hline 22 & $\mathrm{SiO}_{2}$ & 80 & 40 & 500 \\
\hline 23 & $\mathrm{SiO}_{2}$ & 90 & 120 & 500 \\
\hline 24 & $\mathrm{SiO}_{2}$ & 90 & 40 & 500 \\
\hline 25 & $\mathrm{SiO}_{2}$ & 90 & 120 & 500 \\
\hline 26 & $\mathrm{SiO}_{2}$ & 100 & & 500 \\
\hline 27 & $\mathrm{SiO}_{2}$ & 100 & 100 & 500 \\
\hline & & & &
\end{tabular}

\section{RESULTS AND DISCUSSIONS}

The microhardness and corrosion rate values obtained from experimentation is shown in Table VII.

TABLE VII: Experimental of microhardness and corrosion rate values

\begin{tabular}{|c|c|c|c|c|c|c|}
\hline Exp. No. & $\begin{array}{c}\text { Nano } \\
\text { material }\end{array}$ & $\begin{array}{c}\text { Bath } \\
\text { Temperature } \\
\left({ }^{\circ} \mathrm{C}\right) \\
\end{array}$ & $\begin{array}{c}\text { Plating } \\
\text { Time } \\
\text { (min.) } \\
\end{array}$ & $\begin{array}{l}\text { Speed of } \\
\text { stirring }\end{array}$ & $\begin{array}{c}\text { Microhardness } \\
\text { (H.v.) }\end{array}$ & $\begin{array}{c}\begin{array}{c}\text { Corrosion } \\
\text { rate } \\
(\mathrm{mmpy})\end{array} \\
\end{array}$ \\
\hline 1 & $\mathrm{TiO}_{2}$ & 80 & 40 & 500 & 201.4 & 1.734 \\
\hline 2 & $\mathrm{TiO}_{2}$ & 80 & 80 & 500 & 265.8 & 7.126 \\
\hline 3 & $\mathrm{TiO}_{2}$ & 80 & 120 & 500 & 274.3666667 & 4.844 \\
\hline 4 & $\mathrm{TiO}_{2}$ & 90 & 40 & 500 & 221.3333333 & 9.976 \\
\hline 5 & $\mathrm{TiO}_{2}$ & 90 & 80 & 500 & 417.8666667 & 4.136 \\
\hline 6 & $\mathrm{TiO}_{2}$ & 90 & 120 & 500 & 254.5 & 1.255 \\
\hline 7 & $\mathrm{TiO}_{2}$ & 100 & 40 & 500 & 340.1333333 & 5.736 \\
\hline 8 & $\mathrm{TiO}_{2}$ & 100 & 80 & 500 & 164.2 & 5.502 \\
\hline 9 & $\mathrm{TiO}_{2}$ & 100 & 120 & 500 & 341.2 & 4.182 \\
\hline 10 & $\mathrm{Al}_{2} \mathrm{O}_{3}$ & 80 & 40 & 500 & 128.0666667 & 3.855 \\
\hline 11 & $\mathrm{Al}_{2} \mathrm{O}_{3}$ & 80 & 80 & 500 & 248.4333333 & 8.436 \\
\hline 12 & $\mathrm{Al}_{2} \mathrm{O}_{3}$ & 80 & 120 & 500 & 321.0333333 & 1.089 \\
\hline 13 & $\mathrm{Al}_{2} \mathrm{O}_{3}$ & 90 & 40 & 500 & 354.5666667 & 1.375 \\
\hline 14 & $\mathrm{Al}_{2} \mathrm{O}_{3}$ & 90 & 80 & 500 & 316.2 & 1.179 \\
\hline 15 & $\mathrm{Al}_{2} \mathrm{O}_{3}$ & 90 & 120 & 500 & 352.5 & 8.979 \\
\hline 16 & $\mathrm{Al}_{2} \mathrm{O}_{3}$ & 100 & 40 & 500 & 237.3333333 & 8.78 \\
\hline
\end{tabular}




\begin{tabular}{ccccccc}
\hline 17 & $\mathrm{Al}_{2} \mathrm{O}_{3}$ & 100 & 80 & 500 & 473.8 & 9.574 \\
\hline 18 & $\mathrm{Al}_{2} \mathrm{O}_{3}$ & 100 & 120 & 500 & 394.0333333 & 6.74 \\
\hline 19 & $\mathrm{SiO}_{2}$ & 80 & 40 & 500 & 141.7333333 & 8.12 \\
\hline 20 & $\mathrm{SiO}_{2}$ & 80 & 80 & 500 & 143.3333333 & 4.209 \\
\hline 21 & $\mathrm{SiO}_{2}$ & 80 & 120 & 500 & 138.1333333 & 2.42 \\
\hline 22 & $\mathrm{SiO}_{2}$ & 90 & 40 & 500 & 132.6666667 & 1.641 \\
\hline 23 & $\mathrm{SiO}_{2}$ & 90 & 80 & 500 & 299.1666667 & 1.908 \\
\hline 24 & $\mathrm{SiO}_{2}$ & 90 & 120 & 500 & 509.5666667 & 1.255 \\
\hline 26 & $\mathrm{SiO}_{2}$ & 100 & 40 & 500 & 136.3666667 & 5.652 \\
\hline 27 & $\mathrm{SiO}_{2}$ & 100 & 80 & 500 & 168.1 & 5.895 \\
\hline
\end{tabular}

The desirability approach is used to optimize the process. Desirability may be a way of identifying the operating conditions which provide the most desirable response Each experimental result is transformed into a scale of $(0,1)$ through computing the desirability of (d), in which [1] is extremely desirable and [0] is lowest desirable value [15]. Then, as an optimal combination of parameters, the maximum value of desirability is selected, and the factor setting comparable to that maximum desirability value is chosen. The response is scaled into desirability based on its nature, namely larger-the-better, smaller-the-better, and nominal-the-better. They explain individually as follows:

Larger-The-Better (LTB) The estimated response value is predicted to be larger than a lower bound. For this kind of response, determines the individual desirability function through Eq. (1):

$$
d_{i}(Y)_{i}= \begin{cases}0 & Y<L \\ \left(\frac{Y-L}{T-L}\right)^{r} & L \leq Y \leq T \\ 1 & Y>T\end{cases}
$$

Smaller-The-Better (STB) The estimated response value is predicted to be smaller than an upper bound. For this kind of response, determines the individual desirability function through Eq. (2):

$$
d_{i}(Y)_{i}= \begin{cases}1 & Y<T \\ \left(\frac{U-Y}{U-T}\right)^{r} & T \leq Y \leq U \\ 0 & Y>U\end{cases}
$$

Nominal-The-Better (NTB) The estimated response value is predicted to obtain a particular target value. For this kind of response, determines the individual desirability function through Eq. (3):

$$
d_{i}\left(Y_{i}\right)= \begin{cases}0 & \\ \left(\frac{Y-L}{T-L}\right)^{r_{1}} & Y \leq L \\ \left(\frac{U-Y}{U-T}\right)^{r_{2}} & T \leq Y \leq U \\ 0 & Y>U\end{cases}
$$

where $(\mathrm{Y})$ represents the response, $(\mathrm{U})$ represents the upper limit, $(\mathrm{L})$ represents the lower limit, (T) represents the target value and $(r),\left(r_{1}\right),\left(r_{2}\right)$ represent the weights. After calculating the individual desirability, Eq. (4): is used to calculate overall desirability or composite desirability.

$$
D=\left(d_{1} \times d_{2} \times d_{3} \times \cdots d_{n}\right)=\left(\prod_{i=1}^{n} d_{i}\right)^{1 / n}
$$

where (D) refers for composite desirability, $\left(\mathrm{d}_{1}\right) ;\left(\mathrm{d}_{2}\right) ; \ldots ;\left(\mathrm{d}_{\mathrm{n}}\right)$ refers for maximum desirable values for various response and (n) refers for the number of responses. The experimental data received from Taguchi design processes is analyzed using the (Minitab R19) software which uses a full quadratic response surface model defined through Eq. (5) [16]. 


$$
Y=\beta_{0}+\sum_{i=1}^{k} \beta_{i} x_{i}+\sum_{i=1}^{k} \beta x_{i} x_{i}+\sum_{i<j} \sum \beta_{i j} x_{i} x_{j}
$$

where $(y)$ is the response, $(\beta)$ is the intercept parameter, $\left(\mathrm{x}_{\mathrm{i}}\right)$ is $\left(i^{\text {th }}\right)$ factor, $(\mathrm{k})$ is total number of factors. Response surface equations for corrosion rate and microhardness are given below:

\section{Regression Equation}

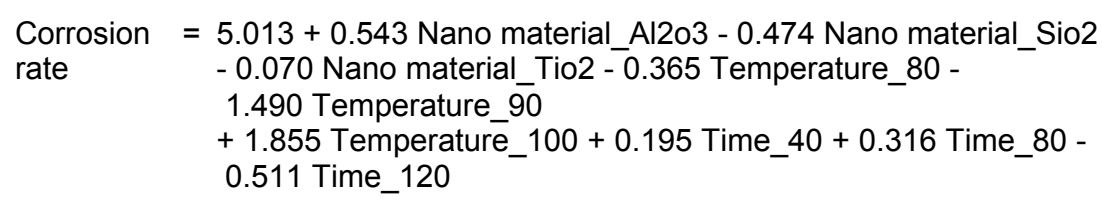

\section{Regression Equation}

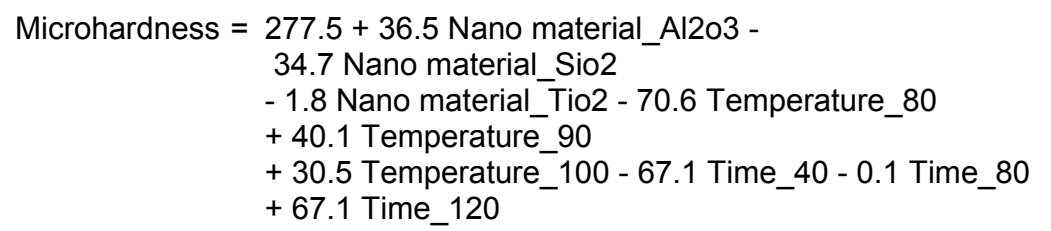

The above equations demonstrate that electroless plating technique factors makes easy regression analysis difficult to predict the output characteristics as a result, to determine the optimum method parameter settings to maximize the microhardness and minimize corrosion rate desirability function (DF) provided by Eq. (4), the optimized process parameters for individually maximizing the microhardness and minimizing corrosion rate by desirability function are shown in Figure 2 (a, b, and c). Figure c shows the optimal factor setting for low carbon steel with optimum corrosion rate and microhardness (multi-responses).
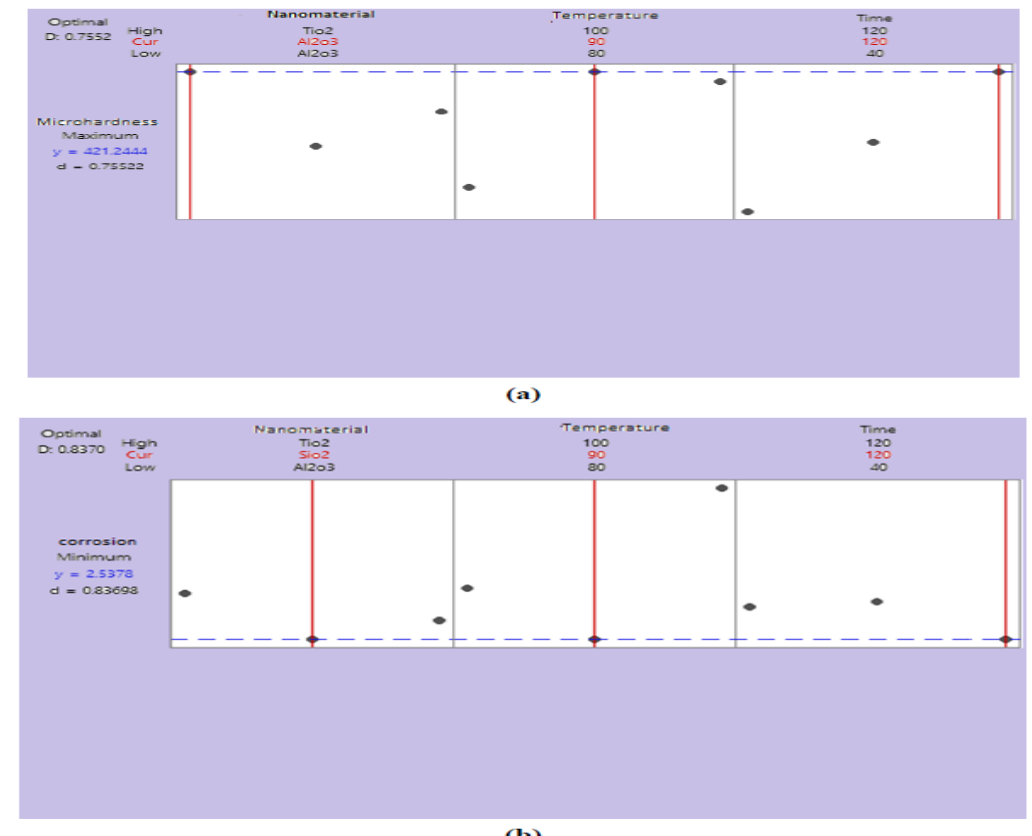

(b)

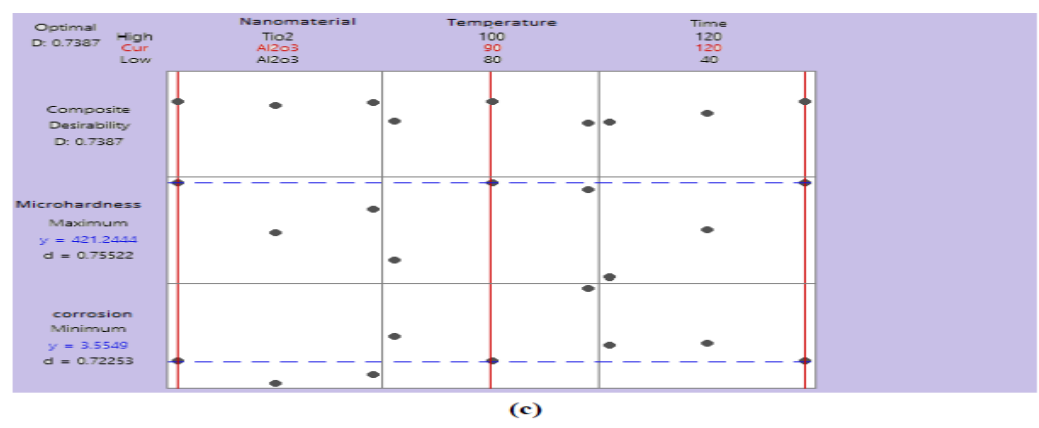


Figure 2: (a) Maximize the microhardness through desirability function, (b) minimize corrosion rate through desirability function, (c) optimization of multi-responses by composite desirability.

Levels of optimum factor are calculated to maximize the desirability function and are presented in Table VIII for relevant responses with their target value. Since all the responses are of no less importance, the weight $\left(\mathrm{w}_{\mathrm{i}}\right)$ value is used as (1). Table IX shows the combined desirability function when maximizing one response and minimizing another response simultaneously together with optimal factor levels.

TABLE VIII: Optimum factor levels and target response

\begin{tabular}{cccccc}
\hline \hline Response & Goal & Lower & Target & Weight & Importance \\
\hline Microhardness & Maximum & 128.06 & 516.26 & 1 & 1 \\
& & 7 & 7 & & 1 \\
\hline Corrosion Rate & Minimum & 1.089 & 9.976 & 1 & 1 \\
\hline
\end{tabular}

TABLE IX: Optimum factor levels and predicted response for individual response

\begin{tabular}{|c|c|c|c|c|c|}
\hline $\begin{array}{c}\text { Bath } \\
\text { temperature } \\
\text { (A) }\end{array}$ & $\begin{array}{l}\text { Plating } \\
\text { time } \\
\text { (B) }\end{array}$ & $\begin{array}{l}\text { Nano- } \\
\text { material } \\
\text { (C) }\end{array}$ & Microhardness & $\begin{array}{l}\text { corrosion } \\
\text { rate }\end{array}$ & $\begin{array}{l}\text { Composite } \\
\text { Desirability }\end{array}$ \\
\hline 90 & 120 & $\mathrm{Al}_{2} \mathrm{O}_{3}$ & 421.244 & 3.55489 & 0.738695 \\
\hline
\end{tabular}

\section{Microstructural Analysis}

The microstructure of electroless plated steel was studied for optimum conditions of the material i.e., at (bath temperature $=90^{\circ} \mathrm{C}$, plating time $=120$ min. and Nanomaterial $\left(\mathrm{Al}_{2} \mathrm{O}_{3}\right)$ ). The microstructural constituents were identified according to (X-ray) diffraction analysis. The (XRD) pattern in optimum condition $\left(\mathrm{A}_{2} \mathrm{~B}_{3} \mathrm{C}_{2}\right)$ is a collection of amorphous-crystalline peaks i.e. The (XRD) plot appear that the $\left(\mathrm{Ni}-\mathrm{P}-\mathrm{Al}_{2} \mathrm{O}_{3}\right)$ Coating is combination of amorphous and crystalline structure as shown in Figure 3.

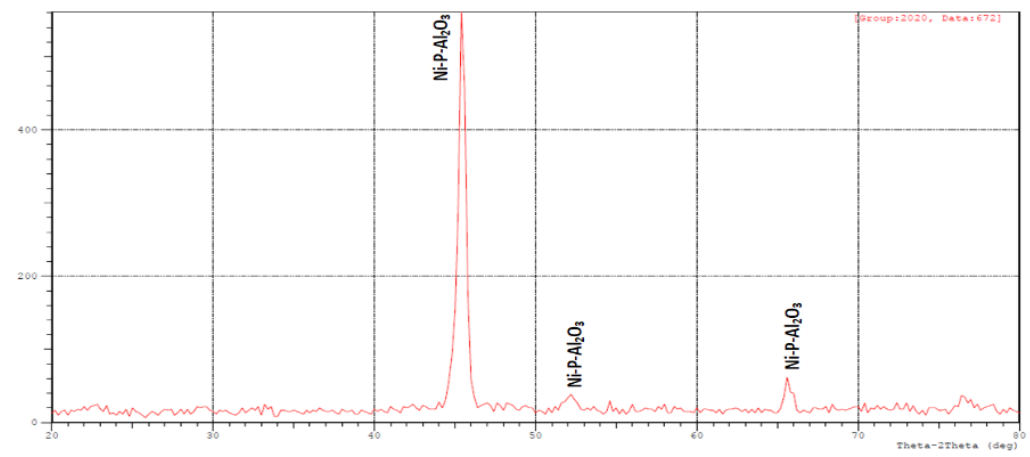

Figure 3: (X-ray) diffraction of electroless $\left(\mathrm{Ni}-\mathrm{P}-\mathrm{Al}_{2} \mathrm{O}_{3}\right)$ coating.

The (ANOVA) approach, became utilized to validate the results of the design factor analysis for the results to be statistically reliable. This is achieved to estimate the percentage contribution for every parameter from electroless plated samples. Nanomaterial was located to be the major method parameter at the responses of the electroless-plated low carbon steel with an impact ratio of $(47 \%)$ based at the (ANOVA) results. Contribution \%, proven in Table X.

TABLE X: Analysis of Variance (ANOVA)

\begin{tabular}{ccccc}
\hline \hline Source & DF & SS & MS & Contribution\% \\
\hline Time & 2 & 22846 & 11423 & $13 \%$
\end{tabular}




\begin{tabular}{ccccc}
\hline \hline Temperature & 2 & 67638 & 33819 & $39 \%$ \\
\hline Nanomaterial & 2 & 81070 & 40535 & $47 \%$ \\
\hline Total & 17155 & \\
& 4 & \\
\hline
\end{tabular}

\section{CONCLUSIONS}

The Taguchi design-based desirability function was used to optimize micro-hardness and corrosion rate during electroless plating of low carbon steel in this study. From this study, the following conclusions were drawn:

1) The (XRD) plot appears that the (Ni-P- $\left.-\mathrm{Al}_{2} \mathrm{O}_{3}\right)$ Coating is a mixture of amorphous and crystalline structure.

2) The optimum combination of method parameters resulting in maximum microhardness and minimum corrosion rate in electroless plated low carbon steel were the following: (bath temperature $=90^{\circ} \mathrm{C}$, plating time $=120 \mathrm{~min}$. and Nanomaterial $=\left(\mathrm{Al}_{2} \mathrm{O}_{3}\right)$ ).

3) It was observed that nanomaterial is the main process parameter on the responses of the electroless-plated low carbon steel with an impact ratio of (47\%) based on the results of (ANOVA).

\section{References}

[1] D. H. Abdeen, M. El Hachach, M. Koc and M. A. Atieh, "A review on the corrosion behavior of nanocoatings on metallic substrates”, Materials, Vol.12, No.2, pp.1-24, 2019.

[2] Y. Zhao, C. Jiang, Xu Z., F. Cai, Z. Zhang, and P. Fu,” Microstructure and corrosion behavior of (Ti) nanoparticles reinforced (Ni-Ti) composite coatings by electrodeposition" Materials and Design, Vol.85, No.800, pp.39-46, 2015.

[3] S. A. Iranagh and M. Zarif," $\left(\mathrm{TiO}_{2}\right)$ nano-particle effect on the chemical and physical properties of (Ni-P$\mathrm{TiO}_{2}$ ) nanocomposite electroless coatings", J-Nanostruct, Vol.10, No.2, pp.415-42, 2020.

[4] M. M. Shinyar, L.K. Abbas \& A. Kh. Hussein, "Optimization of mechanical behavior of (Ni-P) nanocomposite coatings using taguchi approach", International Journal of Mechanical and Production Engineering Research and Development (IJMPERD), Vol.10, No.1, pp.99-110, 2021.

[5] B.H. Chen, L. Hong, Y. Ma Y, \& T.M. Ko, "Effects of surfactants in an electroless nickel-plating bath on the properties of (Ni-P) alloy deposits", Ind. Eng. Chem. Res; Vol.41, No.11, pp.2668-2678, 2002.

[6] W. P. Wu, and J. J. Jiang, "Effect of plating temperature on electroless amorphous (Ni-P) film on Si wafers in an alkaline bath solution". Applied Nanoscience, Vol.7, No.6, pp.325-333,2017.

[7] M. M. Arani, M. Gh. Arani, O. Amiri, M. S.Niasari, "CdSnO 3 -graphene nanocomposites: ultrasonic synthesis using glucose as capping agent and characterization for electrochemical hydrogen storage", Ultrasonics Sonochemistry, Vol.61, No.1, pp.1-12, 2020.

[8] P. N. Tri, TA. Nguyen, P. Carriere, \& C.N. Xuan, "Nanocomposite coatings: preparation, characterization, properties, and applications". International Journal of Corrosion, Vol.8, pp:1-19, 2018.

[9] J. Sudagar, J. Lian \& W. Sha," Electroless nickel, alloy, composite and nano coatings-a critical review", Journal of Alloys and Compounds, Vol.571, pp.183-204, 2013.

[10] M. Uysal, "Electroless codeposition of (Ni-P) composite coatings: effects of graphene and $\left(\mathrm{TiO}_{2}\right)$ on the morphology, corrosion, and tribological properties", Metall. Mater. Trans. A Phys. Metall. Mater. Sci., Vol. 50, No. 5, pp. 2331-2341, 2019.

[11] M. Ram, M. Kumar, A. Ansari, S. Sharma, and A. Sharma, "Corrosion resistance of electroless (Ni-P-SiC/ $\mathrm{Ni}-\mathrm{P}-\mathrm{TiO}_{2}-\mathrm{ZrO}_{2}$ ) nano-coatings in paper mill bleach plant”, Mater. Today Proc., Vol.21, No.2, pp.12001212,2020 .

[12] A. K. Hussein, L. K. Abbas, and W. N. Hasan, "Optimization of heat treatment parameters for the tensile properties of medium carbon steel”, Engineering and Technology Journal, Vol. 36, Part A. No. 10, pp.10911099, 2018. 
[13] A. K. Hussein, L. K. Abbas, and W. N. Hasan, "Effect of quenching media variations on the mechanical behavior of martensitic stainless steel”, Al-Khwarizmi Engineering Journal, Vol. 15, No. 2, pp.1- 12, 2019.

[14] A. K. Hussein, L. K. Abbas, and A. A. Seger, "Multi-objective optimization of friction stir welding for aluminum alloy (2024-T3)”, Engineering and Technology Journal, Vol. 38, Part A. No.2, pp.185-198, 2020.

[15] B. John, "Application of desirability function for optimizing the performance characteristics of carbonitrided bushes", International Journal of Industrial Engineering Computations, Vol.4, No.3, pp.305$314,2013$.

[16] H. Lee, I. J. Jeong, and K. J. Kim, "A desirability function method for optimizing mean and variability of multiple responses using a posterior preference articulation approach", Quality and Reliability Engineering International, Vol.34, No.3, pp.360-376, 2018. 